\title{
EVALUATING THE IMPACTS OF FLOODING ON THE RESIDENTS OF LAGOS, NIGERIA
}

\author{
CYNTHIA E. ATUFU* ${ }^{*} \&$ CHRISTOPHER P. HOLT ${ }^{\dagger}$ \\ Faculty of Arts, Science and Technology, University of Northampton, UK
}

\begin{abstract}
The occurrence of natural disasters is of growing concern globally due to increasing disruption, damage and loss of life. The rising flood frequency in Lagos, Nigeria, emphasises the need for improved flood prevention and management measures. This study evaluates the impacts of flooding on the residents of Lagos, Nigeria by focusing on five areas: Lekki, Victoria Island, Ikeja, Surulere and Ikorodu. Each area represents a different income level and population density. Flood managers in Lagos were also interviewed to understand the flood management and prevention situation from the government's perspective, together with the barriers and drivers to effective flood management. Data collected from residents indicate that heavy rainfall, blocked and/or failure of drainage systems, and lack of land use planning were considered the most frequent contributors to the flooding problem. A high proportion of residents live in flood prone areas, having been unaware of the initial flood problem, or selecting the area due to proximity to work or affordability. Government initiated flood awareness campaigns aimed to inform residents. However, some residents continue to live in homes at risk from flooding due to sentimental values, whilst others simply cannot afford to move houses. Results revealed some of the impacts of flooding include displacement, damage to property, and disruption to movement and health issues. The study recommends that residents need to be more aware of proper waste disposal. The government also needs to implement controls on development on flood plain, ensure better and regular waste collection methods, proper maintenance of drainage systems and better flood defences are in place. Also, offering incentives should be in place for residents willing to move to minimise impacts of flooding.
\end{abstract}

Keywords: flooding, flood management, urban flood risk, communities, land use planning, land use management, flood risk perception, flood impacts, resilience.

\section{INTRODUCTION}

Approximately half of the global population currently live in urban areas, an increase of almost 25\% since 1950 [1]. The United Nations [1] has suggested that the urban population will rise by an additional 2.5 billion people by 2050 , with almost $90 \%$ of this increase concentrated in Africa and Asia. Nigeria, together with China and India are expected to account for almost $40 \%$ of this growth. Lagos city has seen significant growth since 1881 when the settlement was almost $4 \mathrm{~km}^{2}$ in size [2] to its current status as a megacity covering an area of over $1,100 \mathrm{~km}^{2}$ [3].

As the global urban population increases, the proportion of residents exposed to environmental hazards, including flooding, has and will increase. Where a variable climate system combines with an increasingly unpredictable rainy season and a flood management infrastructure incapable of coping with events, the risk of flooding is exacerbated. More important is the development on land already vulnerable to flooding that will increase the risk of flooding in these areas. The share of the flood risk burden tends to be greater in developing countries and has a disproportionate impact on the poorer sections of the community [4].

\footnotetext{
* ORCID: https://orcid.org/0000-0002-3991-8981

$\dagger$ ORCID: https://orcid.org/0000-0002-5775-9048
} 
The city of Lagos, southwest Nigeria, is bordered to the south by the Atlantic Ocean, thereby increasing developmental pressure on the available land. Already the population density in Lagos exceeds 2,500 persons $/ \mathrm{km}^{2}$ compared with just over 150 for Nigeria as a whole [5]. Lagos became the capital city of Nigeria following the amalgamation of several states in 1914 and remained the nation's capital following independence in 1960 until its replacement in 1991 by Abuja as the federal capital. Due to its former position as the nation's capital together with its commercial importance, inward migration into Lagos State, and the city itself, has led to a significant growth in the city's population from over 760,000 in 1960 to over 9 million by 2006 and is projected to increase to 25 million by 2025 [6], making Lagos city the third largest megacity in the world. The vulnerability of megacities to natural hazards is affected by both their physical and social exposure, along with preparedness prior to an event, resilience, and response following the event [7].

\section{FLOODING IN LAGOS}

The Lagos climate is equatorial, with rainfall throughout the year, however most of the precipitation falls during the rainy season, usually between March or April and September or October [8]. Average monthly rainfall during the rainy season can exceed $200 \mathrm{~mm}$, typically greater than the infiltration capacity of the soils rapidly leading to the generation of runoff that overwhelms the drainage system (both natural and anthropogenic) [9].

Lagos has a low-lying topography with slopes typically between $1-4 \%$, and elevations ranging from or below sea level to approximately $2 \mathrm{~m}$ above sea level [10]. The low slope angle delays the drainage of water from the land, which combined with the increase in runoff generation associated with urban expansion, increases the flood risk over time. Flooding has been an issue in Nigeria certainly since the 1950s [9], although the earliest available historical record of flooding in Lagos dates back to July 1947 [11], with the event being caused by a period of heavy rainfall. Despite the long history of flooding in Lagos, the growth of unplanned settlements in the city has compounded the flood issue with only $45 \%$ of the urban area being served by storm drains [12], of which less than $30 \%$ are regularly maintained [13].

The speed and extent of urbanisation in Lagos, combined with unplanned growth [14] has led to an increase in flood episodes, to the point where they have become a perennial problem. Flooding in Lagos is now an annual even with the exception of the drought year of 1973 [9]. The heightened risk of flooding in Lagos during the wet season has been recognised as an issue since at least the 1970s when residents considered it one of the three most important environmental problems [15]. Typically flooding in the area is caused by either shortduration high-intensity rainfall or long-duration low intensity rainfall, the frequency of both having increased compared to 30 years ago [16].

Flooding in 2010, 2011 and 2012 have helped to raise the general awareness of the flood problem in Lagos, though they also demonstrate the scale of the problem that must be overcome. All three of the floods had the same basic impacts: displacement of residents, damage to property, disruption to communications and loss of life. The 2010 flood affecting Ikorodu caused significant damage and the relocation of thousands of residents, of whom over 1700 had to be provided with accommodation by the Lagos State government for over 10 months [17]. The following year's flooding led to the costliest claims settlement in the history of the Nigerian insurance industry, estimated to range from between US\$200 million [17] to over US\$300 million [18], though it should be noted that a significant number of low and middle-income properties were also affected but uninsured. The flooding in 2012 was considered the worst flood event in over 40 years [9] affecting 7.7 million people including over 500 residents whose injuries were considered either a direct or indirect result of the flood and over 2 million residents displaced by the flood waters. 


\section{METHODS}

\subsection{Study site}

Lagos comprises sixteen Local Government Areas (LGAs). Five of these LGAs (Fig. 1) were selected due to their range in population, income and housing types (including slum areas), as well as the variation in flood experience and vulnerability together with the flood management strategies in place. Lagos is considered by residents to be split into two areas: The Island (represented by Lekki and Victoria Island) and the Mainland (represented by Ikeja, Surulere and Ikorodu). The Island is viewed as the most prestigious area, with properties selling at a premium. In addition, most of Nigeria's financial institutions have their headquarters in Lekki and Victoria Island along with many businesses of all sizes.

The Mainland includes a mixture of high cost, generally affordable and low cost (slum) housing. Lagos State's capital is based in Ikeja along with the domestic and international airports. Surulere is dominated by a mixture of middle and low-cost housing, including slum areas as well as being the home to many small to medium sized businesses, while Ikorodu is more of a residential LGA, with a greater proportion of low-cost housing areas compared with medium-cost.

\subsection{Data collection}

All five LGAs are vulnerable to flooding, though the sampling of the residents was stratified by the population of the area (Table 1). 600 questionnaires were distributed on an opportunistic basis to residents in the areas. 150 questionnaires distributed in both Ikorodu and Surulere, and 100 each in Lekki, Victoria Island and Ikeja. The overall response rate was 47\%, comprising 161 males (57\%) and 123 females (43\%).

\section{RESULTS AND DISCUSSION}

\subsection{Experience of flooding}

Of the residents questioned, almost $80 \%$ had personal experience of having been flooding whilst living in Lagos, with almost $60 \%$ having been flooded in their current property. The high proportion of residents having experienced flooding fits with Lagos being the most susceptible Nigerian state to flooding due to its coastal location and urban expansion [9]. There was limited variation in the proportion of residents who had experienced flooding in their current properties (Table 2) across the five LGAs, with Ikeja experiencing the lowest proportion of approximately $54 \%$, while residents in Lekki were more likely $(65 \%)$ to have been flooded in their current property. The slightly lower experience of flooding in Ikeja can be partially attributed to the area having well maintained drainage systems, including those designed specifically for the removal of storm water. It is possible that the well-maintained storm water infrastructure and flood defences has been driven by the affluence of the area, together with its importance as the home of the State Government and site of both the domestic and international airports.

Despite the well-maintained flood protection infrastructure, they were designed to cope with a smaller volume of runoff, and their ability to handle flood waters is increasingly compromised by urbanisation over time. Lekki contained the largest proportion of participants who had experienced flooding in their current residence. This area is considered a highly desirable place to live due to its proximity to the coast and relatively recent 


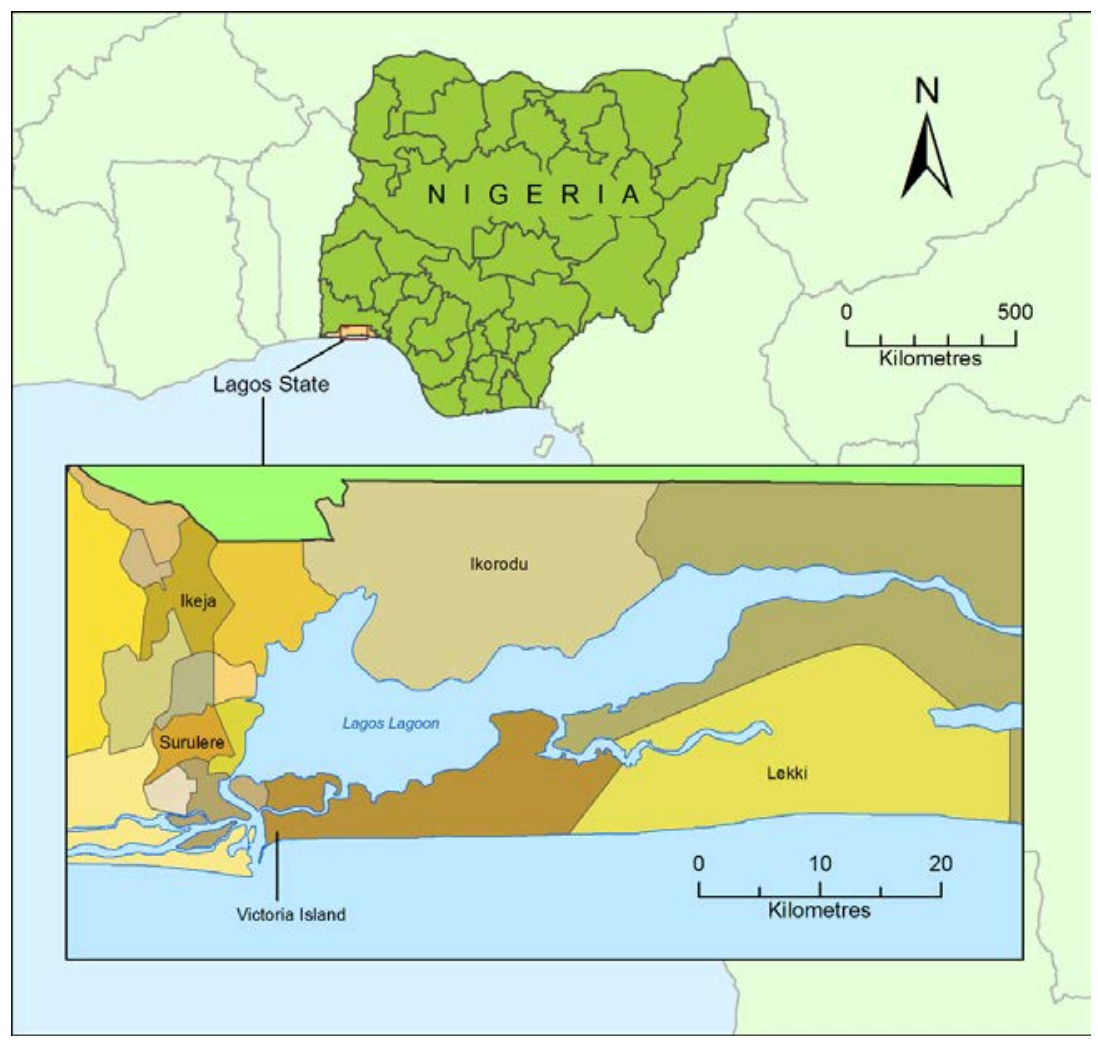

Figure 1: Location of areas surveyed in Lagos, Nigeria.

Table 1: Population and area of the LGAs, with questionnaire response rates [19], [20].

\begin{tabular}{lcccc}
\hline LGA & $\begin{array}{c}\text { Population } \\
(2006 \text { census })\end{array}$ & Area $\left(\mathrm{km}^{2}\right)$ & $\begin{array}{c}\text { Number } \\
\text { of } \\
\text { responses }\end{array}$ & $\begin{array}{c}\text { Response } \\
\text { rate (\%) }\end{array}$ \\
\hline Ikorodu & 527,917 & 345.0 & 59 & 39.3 \\
Ikeja & 317,614 & 49.9 & 65 & 65.0 \\
Lekki & 117,793 & 55.0 & 51 & 51.0 \\
Surulere & 502,865 & 23.0 & 56 & 37.3 \\
Victoria Island & 283,791 & 193.5 & 53 & 53.0 \\
\hline
\end{tabular}

Table 2: Proportion of participants who have experienced flooding in their current property.

\begin{tabular}{lc}
\hline District & $\begin{array}{c}\text { Percentage of participants } \\
\text { having experienced flooding }\end{array}$ \\
\hline Ikorodu & 61.0 \\
Ikeja & 53.8 \\
Lekki & 64.7 \\
Surulere & 58.9 \\
Victoria Island & 60.4 \\
\hline
\end{tabular}


development, however much of the area is reclaimed land, thereby heightening the flood risk during episodes of moderate to heavy rainfall. Whilst most of the high value development has been planned, the intense competition for space combined with the low relief, has made this LGA more vulnerable to flooding. Victoria Island is in a similar situation to Lekki, unlike Ikorodu and Surulere. Although Victoria Island is an area characterised by offices and high residential properties, corner shops line the street, accounting for some of the indiscriminate waste disposal that can end up blocking drainage channels. Both Ikorodu and Surulere contain a mixture of mid- and low-cost housing, though there is a slightly greater proportion of unplanned housing in the former LGA.

Previous experience of flooding usually increases risk perception [17], [21] however, despite $80 \%$ of participants having experienced flooding while living in Lagos, only $20 \%$ considered the flood risk when selecting their current property (Table 3). No relationship was found between location and consideration of the flood risk when selecting a property, $\mathrm{X}^{2}(4$, $\mathrm{n}=55)=7.27, \mathrm{p}>0.05$.

The reason for choosing a property appears to be driven by a variety of factors (Table 4). Taking the participants as a whole, the main reasons ranged from the need for secure or private accommodation (26\%) down to proximity to work $(6 \%)$. Though there were differences between the areas. Affordability were important reasons when considering properties in Ikeja and Victoria Island. The availability of properties at the time of purchase accounted for just over $20 \%$ of participants. Where incomes were low, such as in Ikorodu, the main driver for selecting a property in this area was whether it was in a secure or private area $(25 \%)$. Approximately $10 \%$ of participants did not choose the property in which they currently live, this was typically due to the property being inherited, though a few of the respondents were dependents (18\% of respondents).

\subsection{Perception of flood causes}

Flooding in Lagos usually occurs during the rainy season, although there are a number of factors that can exacerbate the likelihood of a flood occurring in a particular area. The

Table 3: Consideration of flooding when selecting a property.

\begin{tabular}{lcccccc}
\hline \multirow{2}{*}{$\begin{array}{l}\text { Consideration } \\
\text { of flooding }\end{array}$} & Ikorodu & Ikeja & Lekki & $\begin{array}{c}\text { Victoria } \\
\text { Island }\end{array}$ & Surulere & Total \\
\cline { 2 - 7 } & $10(16.9 \%)$ & $17(26.2 \%)$ & $6(11.8 \%)$ & $14(26.4 \%)$ & $8(14.3 \%)$ & $55(19.4 \%)$ \\
Yes & $27(45.8 \%)$ & $28(43.1 \%)$ & $35(68.6 \%)$ & $23(43.4 \%)$ & $37(66.1 \%)$ & $150(52.8 \%)$ \\
No & $14(23.7 \%)$ & $15(23.1 \%)$ & $0(0 \%)$ & $12(22.6 \%)$ & $1(1.8 \%)$ & $42(14.8 \%)$ \\
Don't know & $8(13.6 \%)$ & $5(7.7 \%)$ & $10(19.6 \%)$ & $4(7.5 \%)$ & $10(17.9 \%)$ & $37(13.0 \%)$ \\
\hline No response & $8(7.9 \%)$ & & & &
\end{tabular}

Table 4: Main reasons for choosing current property by area (number and percentage).

\begin{tabular}{lcccccc}
\hline \multirow{2}{*}{ Cause } & \multicolumn{6}{c}{ LGA } \\
\cline { 2 - 7 } & \multirow{2}{*}{ Ikorodu } & Ikeja & Lekki & $\begin{array}{c}\text { Victoria } \\
\text { Island }\end{array}$ & \multirow{2}{*}{ Surulere } & \multirow{2}{*}{ Total } \\
\hline Availability & $8(13.6 \%)$ & $17(26.2 \%)$ & $12(23.5 \%)$ & $14(26.4 \%)$ & $14(25 \%)$ & $65(22.9 \%)$ \\
Security/privacy & $15(25.4 \%)$ & $2(3.1 \%)$ & $28(54.9 \%)$ & $2(3.8 \%)$ & $27(48.2 \%)$ & $74(26.1 \%)$ \\
Affordability & $10(16.9 \%)$ & $15(23.1 \%)$ & $1(2.0 \%)$ & $13(24.5 \%)$ & $1(1.8 \%)$ & $40(14.1 \%)$ \\
Did not choose & $6(10.2 \%)$ & $12(18.5 \%)$ & $0(0 \%)$ & $11(20.8 \%)$ & $0(0 \%)$ & $29(10.2 \%)$ \\
Proximity to work & $5(8.5 \%)$ & $6(9.2 \%)$ & $0(0 \%)$ & $4(7.5 \%)$ & $2(3.6 \%)$ & $17(6.0 \%)$ \\
No response & $13(22.0 \%)$ & $5(7.7 \%)$ & $10(19.6 \%)$ & $4(7.5 \%)$ & $10(17.9 \%)$ & $42(14.8 \%)$ \\
\hline
\end{tabular}


Table 5: Perception of causes of flooding per area as a percentage of respondents.

\begin{tabular}{lccccc}
\hline \multirow{2}{*}{ Cause } & \multicolumn{5}{c}{ LGA } \\
\cline { 2 - 6 } & Ikorodu & Ikeja & Lekki & $\begin{array}{c}\text { Victoria } \\
\text { Island }\end{array}$ & Surulere \\
\hline Heavy rainfall & 64.4 & 56.9 & 64.7 & 62.3 & 60.7 \\
Flooding from river or lagoon & 15.3 & 26.2 & 13.7 & 28.3 & 12.5 \\
Failure of storm drains & 39.0 & 26.2 & 45.1 & 30.2 & 39.3 \\
Waste disposal & 10.2 & 6.2 & 23.5 & 9.4 & 19.6 \\
Lack of appropriate drainage & 6.8 & 12.3 & 9.8 & 17.0 & 7.1 \\
Other & 10.2 & 16.9 & 23.5 & 22.6 & 19.6 \\
\hline
\end{tabular}

majority of residents (over 60\%) (Table 5) attributed the cause of flooding to episodes of heavy rainfall. This brings with it the issue of seasonality and therefore a usually clearly defined time during the year when the risk of flooding will be at its greatest. It could be argued that other causes identified such as failure of the storm drains or flooding from the river or lagoon are indeed associated with the heavy rainfall. However, residents were very clear in terms of what they perceived to be the main cause, for example the failure of the storm drains to cope with the volume of runoff being seen as a separate issue. Residents in Lekki (just over $45 \%$ of residents) felt that the failure of storm drains to cope with the volume of runoff was an issue which raises challenges for flood management in this particular location. The low elevation and its location by the coast, combined with the fact that much of this area has been reclaimed, means that effective surface drainage is going to be challenging at the best of times. The aging nature of storm drains across the city poses an additional challenge to the effective management of runoff, due to the lack of expansion of the storm water drainage system capacity to keep up with the increased volume of runoff generated by the expanding urban area.

Ikorodu is already highly congested, with competition for the available open space leading to many new properties being built on the floodplain. Due to the expansion into low lying areas, where drainage is less effective, a greater proportion of respondents from Ikorodu attributed the cause of flooding to heavy rainfall.

Although rainfall was the main cause of flooding, direct human activity also played a role. The failure of storm drains to cope with the volume of runoff was considered, by residents from all five LGAs, the second most important cause of flooding, ranging from 26 to $45 \%$ (Table 5). Lack of drainage was seen as important cause in most areas although the problems of storm drains being blocked by inappropriate disposal of waste was percieved to be a greater issue especially in Lekki and Surulere. The fact that the two LGAs at opposite ends of the property value spectrum have similar perceptions of the impact of incorrect waste disposal as a flood cause is of particular interest. The blockage of drainage systems due to inadequate waste disposal and collection is an issue with regards to increasing the flood risk [12], though not one restricted to just Lagos or indeed Nigeria alone. The issue of poor waste management and collection has previously been identified as a causal factor in flood initiation [22], with 7\% of residents in the area of Mile 12, Lagos agreeing that flooding was often caused by waste blocking drainage channels. Waste does however play a more complicated role within some communities in Lagos. In the Badia community waste is actively collected and used for three purposes: a cheaper alternative to sand filling when constructing the foundations for a house; a material used for flood control during the rainy season; and income generation for the garbage collectors and unauthorised developers who use it to fill parts of the canal prior to selling the reclaimed land for development [23]. 


\subsection{Impact of flooding on residents}

Flooding has the potential to have wide-ranging impacts within the community it affects causing significant disruption to day-to-day life, communications and to both the local and potentially national economies [24]. The impacts on the residents of Lagos varied with the highest proportion (38\%) experiencing damage to property (Table 6). This can often bring serious hardship to residents in the aftermath of the flood due to inadequate or more often lack of insurance cover. Lack of insurance cover tends to disproportionately affect those in the lower income brackets, making their recovery in the aftermath of the flood even more challenging.

Disruption to day-to-day life, including travelling around Lagos was the second highest impact (Table 6). In addition to the disruption caused by the depth and volume of water, floods also damage public road surfaces through the creation of potholes that make safe transportation and ease of movement difficult. Whilst it is not unusual for residents to attempt to travel around the area in their vehicles, the majority, especially from the low-income areas, will try and wade through the water, though it is more likely that they will remain in their homes, unable to get to work, or in some cases get back to their property. Approximately one third of respondents had lost property and/or had been forced to abandon their properties until the floodwaters subsided.

The lack of pre-flood preparedness meant that flooding has had a more direct impact on the residents, with just over $10 \%$ either being hospitalised or had an immediate member of the family hospitalised due to the flooding. Flooding in Lagos does unfortunately cause fatalities with approximately $5 \%$ of participants losing a family member or being aware of a death in their immediate neighbourhood.

Despite the regularity of flooding, due in part to the lack of an appropriate flood management infrastructure across the whole city, and the expansion of the city into areas more at risk from the annual floods, the government appears to be taking a reactive approach rather than being proactive. This could be due to a combination of the rapid growth of Lagos, and the expansion of unplanned developments within the city, plus the scale of the problem worsened by the lack of maintenance and improvement in the existing flood management infrastructure. The government response is further compromised by failure of warnings to reach residents in parts of the city due to regular power cuts [23], and where these are received, they are treated with distrust, under the belief that the flood warning and request to evacuate an area is in fact a means of evicting residents from slum areas. This mistrust has been caused by this technique being used to move over 300,000 slum residents from Maroko in Victoria Island in 1990 [20]. Even though there is distrust of government action amongst certain section of the communities in Lagos there appears to be little concerted effort amongst residents to minimise their future flood risk. Where action is taken, it is the local community

Table 6: Impacts experienced by residents.

\begin{tabular}{lcc}
\hline Impact & Number & Percentage \\
\hline Loss of property & 95 & 33.5 \\
Disruption & 97 & 34.2 \\
Displacement & 89 & 31.3 \\
Damage to property & 109 & 38.4 \\
Hospitalisation & 32 & 11.3 \\
Loss of life & 16 & 5.6 \\
\hline
\end{tabular}


who tend to take responsibility (40\%) and drive the modifications needed to reduce future flood risk and impacts (Table 7). Only 16\% of residents felt that there had been a government response. While direct action by individuals and families, and landlords was taken by $5 \%$ or less of participants. With regards to individuals and families this suggests a resignation to being flooded annually. The Landlords' Association in Lagos is currently pressing the government to take more action yet appear to be the least likely to take the initiative to minimise the risk to their own properties.

Actions taken by the various parties tend to draw on a limited range of activities. The use of sandbags to keep water out of properties and the raising of the entrance to the property were the most common practices (Table 8). The blockage of drainage systems with waste is potentially an easy issue to resolve yet is the least popular of the actions. This particular action tends to be more likely to be undertaken by the local community rather than individuals. Unfortunately, material excavated from the drainage systems is either dumped by the side of the channels or used to fill depressions in road surfaces. The failure to remove the waste from the locality often leads to the material being washed back into the drainage systems. Previous governments have attempted to foster a sense of community pride by encouraging residents to allocate time each month to clearing channels in their immediate neighbourhood, although this activity seems to have fallen into abeyance in recent years.

Waste bins are provided, although not regularly collected for disposal by the Lagos State Waste Management Authority (LAWMA). The National Orientation Agency tries to improve awareness of the flood risk and what can be done to reduce it via announcements on both television and radio adverts, though the impact appears to be limited and very short lived.

\section{CONCLUSIONS}

Flooding is a natural disaster whose impacts can not be overstated and since flood risk has been projected to increase globally, for a developing city like Lagos with a population of over 9 million people projected to increase to over 25 million by 2025, the impacts of flooding could prove disastrous if better flood prevention and management strategies are not adopted.

Although respondents believed the main cause of flooding to be heavy rainfall events, anthropogenic causes that exacerbated the issue included: terrain (houses on floodplain), attitude to flooding (indiscriminate dumping of waste) and poor planning and maintenance of drainage systems. Houses were built and are still being built on floodplains. The

Table 7: Responsibility for actions to minimise the impact of future flooding.

\begin{tabular}{lcc}
\hline Responsibility & Number & Percent \\
\hline Individual/family & 15 & 5.3 \\
Landlord & 7 & 2.5 \\
Local community & 113 & 39.8 \\
Government & 46 & 16.2 \\
\hline
\end{tabular}

Table 8: Actions taken to minimise flood risk and impact.

\begin{tabular}{lcc}
\hline Action & Number & Percent \\
\hline Sandbags & 105 & 37.0 \\
Raise entrance to property & 89 & 31.3 \\
Fill in depressions around property & 61 & 21.5 \\
Clear drainage systems & 34 & 12.0 \\
\hline
\end{tabular}


government has advised residents to vacate such buildings, however, residents refuse to leave their homes as they have sentimental ties to them despite becoming aware they are at an increased risk to flooding. There also appears to be a diminished sense of environmental stewardship on the part of the government and the residents, including landlords as all parties are aware of the flood situation in Lagos but efforts that have been made or are still being made have not yielded much impact. As population increases, residents need more homes which unfortunately continue to be built on floodplains suggesting the lack of or lax enforcement of planning laws and policies.

These factors coupled with the poor planning and maintenance of drainage systems poses an increasing number of issues for Lagos. There needs to be better laws governing waste disposal, updated and well maintained drainages and effective laws and policies preventing even more people from building on these low-lying areas. It is however, not enough to make laws and policies, these need to be effectively enforced and managed to ensure that all sides are doing their part in reducing flooding and its impacts in Lagos.

\section{REFERENCES}

[1] United Nations, Department of Economic and Social Affairs, Population Division, World Urbanization Prospectus: The 2014 Revision, United Nations: New York, 2015.

[2] Okude, A.S. \& Ademiluyi, I.A., Implications of the changing pattern of land cover of the Lagos coastal area of Nigeria. American-Eurasian Journal of Scientific Research, 1(1), pp. 31-37, 2006.

[3] Nkwunonwo, U.C., Whitworth, M. \& Baily, B., A review and critical analysis of the efforts towards urban flood risk management in the Lagos region of Nigeria. Natural Hazards and Earth System Sciences, 16, pp. 349-369, 2016. DOI: 10.5194/nhess-16349-2016.

[4] Mirza, M.M.Q., Climate change and extreme weather events: Can developing countries adapt? Climate Policy, 3(3), pp. 233-248, 2003. DOI: 10.1016/S14693062(03)00052-4.

[5] Durowoju, O.S., Olusola, A.O. \& Anibaba, B.W., Relationship between extreme daily rainfall and maximum daily river discharge within Lagos metropolis. Ethiopian Journal of Environmental Studies and Management, 10(4), pp. 492-504, 2017. DOI: 10.4314/ejesm.v10i4.7.

[6] Elias, P. \& Omojola, A., Case study: The challenges of climate change for Lagos, Nigeria. Current Opinion in Environmental Sustainability, 13, pp. 74-78, 2015. DOI: 10.1016/j.cosust.2015.02.008.

[7] Cross, J.A., Megacities and small towns: Different perspectives on hazard vulnerability. Global Environmental Change Part B: Environmental Hazards, 3(2), pp. 63-80, 2001. DOI: 10.1016/S1464-2867(01)00020-1.

[8] Israel, A.O., Nature, the built environment and perennial flooding in Lagos, Nigeria: The 2012 flood as a case study. Urban Climate, 21, pp. 218-231, 2017. DOI: 10.1016/j.uclim.2017.06.009.

[9] Nkwunonwo, U.C., Whitworth, M. \& Baily, B., Flooding and flood risk reduction in Nigeria: Cardinal gaps. Journal of Geography and Natural Disasters, 55(1), 2015. DOI: $10.4172 / 2167-0587.10000136$.

[10] Sojobi, A.O., Balogun, I.I. \& Salami, A.W., Climate change in Lagos state, Nigeria: What really changed? Environmental Monitoring and Assessment, 188, p. 556, 2016. DOI: $10.1007 / \mathrm{s} 10661-016-5549-\mathrm{z}$.

[11] Daily Times, Rain causes considerable damage to roads and buildings, 15th Jul. 1947. 
[12] Nwigwe, C. \& Emberga, T.T., An assessment of causes and effects of flood in Nigeria. Scientific Research and Essays, 2(7), pp. 307-315, 2014.

[13] Aderogba, K., Qualitative studies of recent floods and sustainable growth and development of cities and towns in Nigeria. International Journal of Basic and Applied Science, 1, pp. 187-203, 2012. DOI: 10.17142/ijbas-2012.1.2.4.

[14] Obiefuna, J.N., Nwilo, P.C., Atagbaza, A.O. \& Okolie. C.J., Spatial changes in the wetlands of Lagos/Lekki Lagoons of Lagos, Nigeria. Journal of Sustainable Development, 6(7), pp. 123-133, 2013. DOI: 10.5539/jsd.v6n7p123.

[15] Ayoade, J.O. \& Akintola, F.O., Public perception of flood hazard in two Nigerian cities. Environment International, 4(4), pp. 277-280, 1980. DOI: 10.1016/0160-4120 (80)90079-3.

[16] Odjugo, P.A.O., An analysis of rainfall patterns in Nigeria. Global Journal of Environmental Sciences, 4(2), pp. 139-145, 1980. DOI: 10.4314/gjes.v4i2.2455.

[17] Adelekan, I.O. \& Asiyanbi, A.P., Flood risk perception in flood-affected communities in Lagos, Nigeria. Natural Hazards, 80(1), pp. 445-469, 2016. DOI: 10.1007/s11069015-1977-2.

[18] Ajibade, I., McBean, G. \& Bezner-Kerr, R., Urban flooding in Lagos, Nigeria: Pattern of vulnerability and resilience among women. Global Environment Change, 23(6), pp. 1714-1725, 2013. DOI: 10.1016/j.gloenvcha.2013.08.009.

[19] National Population Commission, Censuses 2006 Priority Tables: Priority Table Vol. 4 Age Sex: 04 B Table DS5 Distribution LGA. Online. http://population.gov.ng/wpcontent/themes/expo18/documents/Pr\%20Vol\%204\%20Age\%20Sex.zip. Accessed on: 8 Jan. 2018.

[20] Adelekan, I.O., Vulnerability of poor urban coastal communities to flooding in Lagos, Nigeria. Environment and Urbanization, 22(2), pp. 433-450, 2010. DOI: 10.1177/ 0956247810380141.

[21] Perry, R.W. \& Lindell, M.K., Predicting long-term adjustment to volcano hazard. International Journal of Mass Emergencies and Disasters, 8(2), pp. 117-136, 1990.

[22] Olajuyigbe, A.E., Rotowa, O.O. \& Durojaye, E., An assessment of flood hazard in Nigeria: The case of Mile 12, Lagos. Mediterranean Journal of Social Sciences, 3(2), pp. 367-375, 2012. DOI: 10.5901/mjss.2012.v3n2.367.

[23] Ajibade, I. \& McBean, G., Climate extremes and housing rights: A political ecology of impacts, early warning and adaptation constraints in Lagos slum communities. Geoforum, 55, pp. 76-86, 2014. DOI: 10.1016/j.geoforum.2014.05.005.

[24] Douglas, I., Flooding in African cities, scales of causes, teleconnections, risks, vulnerability and impacts. International Journal of Disaster Risk Reduction, 26, pp. 34-42, 2017. DOI: 10.1016/j.ijdrr.2017.09.024. 